\title{
Predation Potential of the Water Bugs Sphaerodema rusticum on the Sewage Snails Physa acuta
}

\author{
G Aditya, SK Raut ${ }^{+}$ \\ Ecology and Ethology Laboratory, Department of Zoology, University of Calcutta, 35 Ballygunge Circular Road, \\ Kolkata 700019, India
}

\begin{abstract}
The sewage snail Physa acuta is a serious threat to certain economic plants and to the purification plant of sewage works by rendering the biofilters ineffective. Various attempts are being made to control it. The efficacy of the predacious water bugs Sphaerodema rusticum was judged experimentally, in the laboratory in the potential control of $\mathrm{P}$. acuta. It is revealed that, when supplied separately, the first, second and third instar and the adult $\mathrm{S}$. rusticum did not attack $\mathrm{P}$. acuta belonging to 3.1-8 mm, 5.1-8 mm, 7.1-8 $\mathrm{mm}$ and $\leq 3 \mathrm{~mm}$ size classes respectively. In the remaining trials predation rate varied from zero to eight (average 2.3) individuals per predator per day. In experiments with $\mathrm{P}$. acuta belonging to all the size classes supplied together, none, except the first instar $\mathrm{S}$. rusticum, attacked the prey individuals belonging to the lowest $(\leq 3 \mathrm{~mm})$ size class. The first and second instar $\mathrm{S}$. rusticum, in both trials did not attack P. acuta larger than $4 \mathrm{~mm}$ and $5 \mathrm{~mm}$ in shell length respectively. The water bugs belonging to the third, fourth, fifth instar and adult stages though preyed upon P. acuta with 3.1-8 mm shell length. The average rate of predation by a single $\mathrm{S}$. rusticum varied from 0.14-3.08 individuals per day depending upon the size of $\mathrm{P}$. acuta and the stage of $\mathrm{S}$. rusticum. A single $\mathrm{S}$. rusticum, irrespective of instar and adult stages, destroyed on average $4.16 \mathrm{P}$. acuta daily irrespective of sizes. It is estimated that one S. rusticum could destroy 1,360 P. acuta in its life time. The results clearly indicate that the water bug S. rusticum may be used to control the snails $\mathrm{P}$. acuta.
\end{abstract}

Key words: sewage drains - snail - Physa acuta - water bug - Sphaerodema rusticum - predation - India

The snail Physa acuta Draparnaud is thought to be from North America from which it was introduced to Europe (Ali 1993). In recent years it has spread a good deal further. It is now common in certain parts of Australia (Madsen \& Frandsen 1989) and Africa including Madagascar (Brown 1980, Curtis 1991, Brackenbury \& Appleton 1993). In Asia, $P$. acuta has been recorded from Iran, Iraq, Israel, Japan, Macao (Madsen \& Frandsen 1989), Malaysia (Ali 1993) and India (Raut et al. 1995). In all these areas $P$. acuta is a common inhabitant of ponds, streams, river, rice fields and municipality drains (Macha 1971, Brown 1980, Godan 1983, Alexandrawicz 1986, Appleton \& Bailey 1990, Ali 1993, Brackenbury \& Appleton 1993, Raut et al. 1995). P. acuta is a prolific breeder and can survive in polluted waters. It is also able to spent a considerable length of time in the agrihorticultural gardens. Consequently, it can be a serious threat to certain economic plants (Godan 1983) and to the purification plant of sewage works by rendering the biofilters ineffective (Macha 1971). Thus, it is now a serious problem. Though application of molluscicides could give a temporary relief the idea is not being used in view of possible adverse effects on the flora and fauna - algae, bacteria, amoebae and worms which occur in the biofilters. Therefore, the only option left is the employment of biological control agents.

${ }^{+}$Corresponding author. Fax: +91-33-4853277. E-mail: telelink1@vsnl.com

Received 28 June 2001

Accepted 28 January 2002
Following our record of occurrence of $P$. acuta in Kolkata (Calcutta), India (Raut et al. 1995) and in continuation to our studies on the bioecology of this species, we noted predation of water bugs Sphaerodema rusticum on $P$. acuta in the municipality drains in Kolkata. This prompted us to determine the ability of S. rusticum to control P. acuta. Accordingly, we carried out some experiments in the laboratory and the results are communicated.

\section{MATERIALS AND METHODS}

The water bug S. rusticum belongs to the family Belostomatidae in the sub order Heteroptera of the order Hemiptera. It has a 'direct' life cycle: the egg releases the first larval stage that develops by moulting through successive, larger nymph (larval) stages to the sexually mature adult (imago) stage. Both instar and adult of $S$. rusticum are predacious. There are five (first to fifth) instar stages in $S$. rusticum (Mukhopadhyay 1991). The snail $P$. acuta has a similar, but not identical, life cycle - the egg produces an immature hatchling snail that grows through a sexually immature stage until it becomes a sexually mature adult snail (increasing in size until death). Since $P$. acuta occurring in the sewage drains of Kolkata never exceeds $8 \mathrm{~mm}$ in shell length and the freshly emerged hatchlings varied from 1.7-1.9 $\mathrm{mm}$ in shell length they were grouped into six size classes viz. $\leq 3 \mathrm{~mm}$ (hatchlings), 3.1$4 \mathrm{~mm}, 4.1-5 \mathrm{~mm}$ (immature adult), 5.1-6 mm, 6.1-7 mm and 7.1-8 $\mathrm{mm}$ (sexually mature adult) to the note the preference of different instars and adult of $S$. rusticum for the individuals of $P$. acuta belonging to particular size classes, if any. Accordingly, the following experiments were carried out: Experiment I - An individual of S. rusticum belonging to a particular instar stage or adult was exposed to 15 P. acuta belonging to one size class; Experiment II 
- An individual of $S$. rusticum belonging to a particular instar stage or adult was exposed to 15 P. acuta belonging to all the size classes in different combinations, including at least one but never more than ten individuals from a size class, together.

To have the different stages of $S$. rusticum a dozen adult individuals, each with an egg raft on the back, were collected from the pond located in the Ballygunge Science College campus, University of Calcutta, Kolkata, India, during June 26-July 20, 2000. They were maintained in plastic containers containing pond water. Adequate numbers of fresh water snails Lymnaea (Radix) luteola belonging to different size classes were released into the container from time to time with a view to supply food to the water bugs (Raut et al. 1988). The eggs hatched in due course and larval stages, first to fifth, were obtained subsequently, as needed for experiments.

The snails $P$. acuta belonging to different size classes were collected twice, 1,000 on each occasion, from the sewage drains where the water bugs were collected, by the second week of July 2000. These snails were kept in pond water in large plastic containers with a supply of lettuce food ad libitum. The snails deposited a large number of egg masses daily. Some egg masses were scraped carefully from the wall of the plastic container, kept and maintained in small glass beakers containing pond water to get the newly hatched $P$. acuta.

Experiments were carried out in plastic containers, each $15 \mathrm{~cm}$ in diameter and $4 \mathrm{~cm}$ in depth containing $650 \mathrm{ml}$ pond water. The mouth of the container was closed with a piece of muslin. The container was left undisturbed for 24 $\mathrm{h}$. Then, the muslin was removed and the water was released into an enamel tray. The empty shells (sometimes with a little portion of visceral mass inside the shell) of $P$. acuta were isolated and counted to record the rate of predation of the water bug in question. For each individual of $S$. rusticum, irrespective of nymphs and adult, six trials were made with each size class of the prey snails $P$. acuta. A further 36 trials were carried out with mixed sizes of $P$. acuta. An individual, belonging to a particular instar or adult stage of $S$. rusticum, was used for a maxi- mum of three trials. Fresh P. acuta were supplied for each trial. Control trials were carried out simultaneously in all cases by keeping the snails in the containers to note the normal mortality rate daily, in respect to the experiments designed. Several trials were carried out side by side and the observations were completed between July 23 and August 6, 2000. In all cases mean and standard error (SE) were calculated. Analysis of variance (ANOVA) was applied (Campbell 1989) to ascertain the effects of the stage of $S$. rusticum on (i) the rate of predation on a definite size class or total snails consumed, irrespective of size classes, and (ii) the rate of predation on the individuals of one size class supplied alone or in combination with other size classes.

\section{RESULTS}

Experiment $I$ - First, second, third instar and adult $S$. rusticum did not attack $P$. acuta with $3.1-8 \mathrm{~mm}, 5.1-8 \mathrm{~mm}$, 7.1-8 $\mathrm{mm}$ and $\leq 3 \mathrm{~mm}$ in shell length respectively. In the remaining trials, the average rate of predation varied from $0.17 \pm 0.41$ to $5.5 \pm 1.64$ individuals per predator per day in respect to the size of the prey individuals concerned (Table I). The results of ANOVA tests clearly indicate that the rate of predation differs significantly $(\mathrm{P}<0.001: \mathrm{F}=6.88$, $\mathrm{df}=3$ ) with the stages of $S$. rusticum.

Experiment II - The water bugs, except the first instar, did not attack $P$. acuta belonging to the lowest size class. Also, the largest prey individuals belonging to $4.1-8 \mathrm{~mm}$ and 5.1-8 $\mathrm{mm}$ size classes were not attacked by the first and second instar S. rusticum respectively. In other cases, the rate of predation varied from zero to seven individuals per predator per day (Table II). Though S. rusticum belonging to third, fourth, fifth instar and adult stages preyed upon $P$. acuta having 3.1-8 $\mathrm{mm}$ in shell length, the rate of predation varied to some extent (Table II). Such variations in predation rates are statistically significant $(\mathrm{P}<$ $0.05: \mathrm{F}=4.26, \mathrm{df}=3$ ) as is evident from the results of ANOVA tests. That is, the rate of predation differs significantly with the stages of $S$. rusticum.

In both the experiments $S$. rusticum belonging to the third, fourth, fifth instar and adult stages preyed upon $P$.

TABLE I

Range and (mean $\pm \mathrm{SE}$ ) number of Physa acuta destroyed by one Sphaerodema rusticum per day ( $\mathrm{n}=6$ replicates; each nymph/ adult was exposed to each size class of $P$. acuta separately)

\begin{tabular}{|c|c|c|c|c|c|c|}
\hline \multirow{2}{*}{$\begin{array}{l}\text { Size class (shell } \\
\text { length in } \mathrm{mm} \text { ) } \\
\text { of } P \text {. acuta }\end{array}$} & \multicolumn{6}{|c|}{ S. rusticum } \\
\hline & 1st instar & 2nd instar & 3rd instar & 4th instar & 5 th instar & Adult \\
\hline$\leq 3$ & $\begin{array}{c}1-3 \\
(2.17 \pm 0.75)\end{array}$ & $\begin{array}{c}0-3 \\
(1.33 \pm 1.21)\end{array}$ & $\begin{array}{c}0-5 \\
(2.0 \pm 2.45)\end{array}$ & $\begin{array}{c}0-3 \\
(1.83 \pm 0.75)\end{array}$ & $\begin{array}{c}0-1 \\
(0.17 \pm 0.41)\end{array}$ & 0 \\
\hline $3.1-4$ & 0 & $\begin{array}{c}1-2 \\
(1.50 \pm 0.55)\end{array}$ & $\begin{array}{c}1-3 \\
(1.88 \pm 0.75)\end{array}$ & $\begin{array}{c}1-3 \\
(2.0 \pm 0.89)\end{array}$ & $\begin{array}{c}2-8 \\
(4.33 \pm 2.25)\end{array}$ & $\begin{array}{c}4-6 \\
(4.83 \pm 0.75)\end{array}$ \\
\hline $4.1-5$ & 0 & $\begin{array}{c}0-1 \\
(0.17 \pm 0.41)\end{array}$ & $\begin{array}{c}1-2 \\
(1.33 \pm 0.52)\end{array}$ & $\begin{array}{c}1-4 \\
(2.88 \pm 0.75)\end{array}$ & $\begin{array}{c}1-5 \\
(3.5 \pm 1.76)\end{array}$ & $\begin{array}{c}2-6 \\
(4.16 \pm 1.47)\end{array}$ \\
\hline $5.1-6$ & 0 & 0 & $\begin{array}{c}0-1 \\
(0.66 \pm 0.52)\end{array}$ & $\begin{array}{c}1-3 \\
(2.0 \pm 0.89)\end{array}$ & $\begin{array}{c}2-5 \\
(4.17 \pm 1.17)\end{array}$ & $\begin{array}{c}3-7 \\
(5.5 \pm 1.64)\end{array}$ \\
\hline $6.1-7$ & 0 & 0 & $\begin{array}{c}0-1 \\
(0.17 \pm 0.41)\end{array}$ & $\begin{array}{c}0-2 \\
(1.0 \pm 0.89)\end{array}$ & $\begin{array}{c}3-4 \\
(3.33 \pm 0.52)\end{array}$ & $\begin{array}{c}3-7 \\
(4.8 \pm 1.33)\end{array}$ \\
\hline 7.1-8 & 0 & 0 & 0 & $\begin{array}{c}0-1 \\
(0.17 \pm 0.41)\end{array}$ & $\begin{array}{c}0-3 \\
(1.5 \pm 1.05)\end{array}$ & $\begin{array}{c}1-4 \\
(2.5 \pm 1.05)\end{array}$ \\
\hline
\end{tabular}


TABLE II

Range and (mean \pm SE) number of Physa acuta destroyed by one Sphaerodema rusticum per day ( $\mathrm{n}=36$ replicates; each nymph/ adult was exposed to 15 P. acuta individuals belonging to six size classes together, in different combinations)

\begin{tabular}{|c|c|c|c|c|c|c|}
\hline \multirow{2}{*}{$\begin{array}{l}\text { Size class (shell } \\
\text { length in } \mathrm{mm} \text { ) } \\
\text { of P. acuta }\end{array}$} & \multicolumn{6}{|c|}{ S. rusticum } \\
\hline & 1st instar & 2nd instar & 3rd instar & 4th instar & 5 th instar & Adult \\
\hline$\leq 3$ & $\begin{array}{c}1-4 \\
(2.17 \pm 0.9)\end{array}$ & 0 & 0 & 0 & 0 & 0 \\
\hline $3.1-4$ & $\begin{array}{c}0-1 \\
(0.08 \pm 0.28)\end{array}$ & $\begin{array}{c}0-3 \\
(1.03 \pm 0.96)\end{array}$ & $\begin{array}{c}0-4 \\
(0.78 \pm 1.1)\end{array}$ & $\begin{array}{c}0-2 \\
(0.5 \pm 0.8)\end{array}$ & $\begin{array}{c}0-2 \\
(0.77 \pm 0.8)\end{array}$ & $\begin{array}{c}0-2 \\
(0.39 \pm 0.68)\end{array}$ \\
\hline $4.1-5$ & 0 & $\begin{array}{c}0-20-2 \\
(0.22 \pm 0.48)\end{array}$ & $\begin{array}{c}0-3 \\
(1.17 \pm 1.1)\end{array}$ & $\begin{array}{c}0-6 \\
(1.67 \pm 1.6)\end{array}$ & $\begin{array}{c}0-5 \\
(1.61 \pm 1.51)\end{array}$ & $\begin{array}{c}0-6 \\
(1.56 \pm 1.28)\end{array}$ \\
\hline $5.1-6$ & 0 & 0 & $\begin{array}{c}0-2 \\
(0.47 \pm 0.64)\end{array}$ & $\begin{array}{c}0-3 \\
(0.97 \pm 0.94)\end{array}$ & $\begin{array}{c}0-4 \\
(1.51 \pm 1.32)\end{array}$ & $\begin{array}{c}0-6 \\
(2.14 \pm 1.8)\end{array}$ \\
\hline $6.1-7$ & 0 & 0 & $\begin{array}{c}0-2 \\
(0.42 \pm 0.55)\end{array}$ & $\begin{array}{c}0-2 \\
(0.64 \pm 0.75)\end{array}$ & $\begin{array}{c}0-5 \\
(1.83 \pm 1.43)\end{array}$ & $\begin{array}{c}0-6 \\
(2.69 \pm 1.87)\end{array}$ \\
\hline $7.1-8$ & 0 & 0 & $\begin{array}{c}0-1 \\
(0.14 \pm 0.35)\end{array}$ & $\begin{array}{c}0-2 \\
(0.33 \pm 0.53)\end{array}$ & $\begin{array}{c}0-3 \\
(0.94 \pm 0.97)\end{array}$ & $\begin{array}{c}0-7 \\
(3.08 \pm 1.67)\end{array}$ \\
\hline
\end{tabular}

acuta belonging to most of the size classes (Tables I, II). However, the ANOVA tests revealed that only the rate of predation by the adults differed significantly $(\mathrm{P}<0.01: \mathrm{F}$ $=11.8, \mathrm{df}=1$ ) with the size of prey individuals in respect to availability of prey individuals of one specific size class; and the selection of prey individuals of a specific size among mixed size populations of $P$. acuta.

In control experiments, no $P$. acuta, irrespective of the size classes, died during any $24 \mathrm{~h}$ period.

\section{DISCUSSION}

From the results it appears that the water bug $S$. rusticum is an effective predator of the snail P. acuta. It is also evident that the rate of predation is dependent on the stages (instar and adult) of the predator and the size of the prey individuals. Of the six different stages of $S$. rusticum, the fourth and fifth instar individuals are most effective so far, as they attack the prey snails irrespective of their sizes. Adult S. rusticum kill the greatest number of snails even though they ignore the smallest, hatchling snails. Since the first and second instar S. rusticum do not attack larger snails, it is most likely that they are unable to capture them. Similarly, the failure of larger bugs to eat the smallest snails is, perhaps, due to a handling problem. It is known that water bugs face certain problems in feeding upon the prey snails belonging to different size classes and the possible explanations have been given by Raut and Saha (1989) on the basis of their observations on the predation of the water bugs $S$. annulatum on the snails Indoplanorbis exustus, Lymnaea (Radix) acuminata, L. (R.) luteola and Gyraulus convexiusculus.

Adult $S$. rusticum prey equally upon most sizes of $P$. acuta and the variations in number of individuals consumed seem to be related to the greater amount of food present in the larger snails. Thus, 2.5 individuals of 7.1-8 $\mathrm{mm}$ shell length are equivalent to 4.8 individuals of 6.1-7 $\mathrm{mm}$ or 5.5 individuals of 5.1-6 mm size class. As we have no knowledge regarding palatability of the prey in respect to their age and/or size, the gradual fall in the rate of predation with the increasing size of the prey individuals is, absolutely, governed by the amount of food materials the prey individuals contain. This could be judged from the observed destruction of $4.83,4.16,5.5,4.8$ and 2.5 snails without choice of size (Table I), and 0.39, 1.56, 2.14, 2.69 and 3.08 snails with choice of size (Table II) for the successive size classes. In the field, all sizes of snails will probably be available and adult $S$. rusticum would attack some smaller snails, even if larger ones were available. In nature, in absence of other kind of foods, it is probable that an adult $S$. rusticum would kill, on average, a total of $9.86 P$. acuta per day. Of course, it requires field trials to see what really happens.

Fresh water snails are attacked by a number of predators (Hyman 1967, Bay et al. 1976). Though P. acuta, at present, is found in different parts of the globe, reports on their predators in the introduced areas are scarce. In South Africa, Wilken and Appleton (1991) have shown experimentally that $P$. acuta is significantly less susceptible to attack by the indigenous malacophagous leech, Helobdella conifera, than several indigenous species. Maharaj et al. (1992) also obtained similar result using the larvae of the indigenous sciomyzid flies, Sepedon neavei and S. scapularis in South Africa. In contrast, Voelker $(1966,1968)$ is of the opinion that a larva of water bug Limnogeton fieberi consumes, on average, 2.7 individuals of the fresh water snails Biomphalaria glabrata and $P$. acuta in a day. Thus, it appears that a clear-cut account on the rate of predation on $P$. acuta by any predator is not yet available.

From the present study it is evident that a single $S$. rusticum on average destroy 4.16 individuals of $P$. acuta per day. Since a larva of $S$. rusticum takes on average 39 days to attain the adult stage and an adult bug on average survives for 288 days (Mukhopadhyay 1991), a single $S$. rusticum could, potentially, destroy $1,360 P$. acuta individuals in its life time. As the first and second instar $S$. rusticum predominate in nature (Mukhopadhyay 1991), and they feed absolutely on the hatchling $(\leq 3 \mathrm{~mm})$ and immature (3.1-5 mm) P. acuta individuals, efficient management of the predator ( $S$. rusticum) population in the 
sewage drains needs the release of the required number individuals from time to time. This process should prove effective in keeping functionable the biofilters used in purification plant of sewage works (Macha 1971). Also, as a whole, the density of $P$. acuta could be maintained at a desirable level through the release of water bugs from time to time, as needed, and, therefore, there would be no possibility of attack to the agrihorticultural plants (Godan 1983) without endangering the indigenous snail species (Brackenbury \& Appleton 1993).

Thus, it is concluded that the water bugs $S$. rusticum could be employed to manage the populations of the sewage snails $P$. acuta in sewage drains in India and other countries of the tropics. However, before we attempt to do so, some attention should be given to study the food sources of S. rusticum other than P. acuta in the sewage drains to see if there is any preferred food item over $P$. acuta. Though rearing of $S$. rusticum is not a problem (Mukhopadhyay 1991), due attention is also to be given through a specialist breeding unit to ensure the supply of water bugs as needed, from time to time, for release into the sewage drains.

\section{ACKNOWLEDGEMENTS}

To the Head of the Department of Zoology, University of Calcutta for the facilities provided.

\section{REFERENCES}

Alexandrawicz SW 1986. Physa acuta Draparnaud, 1805 (Mollusca, Gastropoda) from the recent Vistula sediments at Tyniec near Cracow. Acta Zool Cracov 29: 355-372.

Ali JH 1993. The distribution of Physa acuta Draparnaud (Gastropoda: Physidae) in Malaysia and its suitability as test material for insecticide toxicity studies. J Med Appl Malacol 5: $129-134$

Appleton CC, Baily IW 1990. Canoeists and water borne diseases in South Africa. S Af Med J 78: 323-326.

Bay EC, Berg CO, Chapman HC, Legner EF 1976. Biological control of medical and veterinary pests. In Theory and Practice of Biological Control, Academic Press, New York, p. 457-479.

Brackenbury TD, Appleton CC 1993. Recolonization of the Umsindusi River, Natal, South Africa, by the invasive gas- tropod, Physa acuta (Basommatophora, Physidae). J Med Appl Malacol 5: 39-44.

Brown DS 1980. Fresh Water Snails of Africa and Their Medical Importance, Taylor and Francis, London, $487 \mathrm{pp}$.

Campbell RC 1989. Statistics for Biologists, 3rd ed., Cambridge University Press, Cambridge, 446 pp.

Curtis BA 1991. Fresh water macro-invertebrates of Namibia. Madoqua 17: 163-187.

Godan D 1983. Pest Slugs and Snails, Biology and Control, Springer-Verlag, Berlin, Heidelberg, New York, 445 pp.

Hyman LH 1967. The Invertebrates, Mollusca I, 6, McGrawHill Book Co., New York, London, 729 pp.

Macha S 1971. Kultureinflusse auf die Molluskenfauna. Tschech Casop Acta Musci Silesiae, Ser A, Sci Nat 20: 121-146.

Madsen H, Frandsen F 1989. The spread of fresh water snails including those of medical and veterinary importance. Acta Trop 46: 139-149.

Maharaj R, Appleton CC, Miller RM 1992. Snail predation by larvae of Sepedon scapularis Adams (Diptera:Sciomyzidae), a potential biocontrol agent of snail intermediate hosts of schistosomiasis in South Africa. Med Vet Entomol 6: 183187.

Mukhopadhyay B 1991. Ecology of the Water Bug Sphaerodema rusticum Fabr, PhD Thesis, University of Calcutta, India.

Raut SK, Saha TC 1989. The role of water bug Sphaerodema annulatum in the control of disease transmitting snails. $J$ Med Appl Malacol 1: 97-106.

Raut SK, Bhaumik S, Das S 1995. Occurrence of the snail Physa acuta Draparnaud in Calcutta, India. J Bombay Nat Hist Soc 92: 434.

Raut SK, Saha TC, Mukhopadhyay B 1988. Predacious water bugs in the control of vector snails. Bicovas 1: 175-185.

Voelker J 1966. Wasserwanzen als obligatorische Schnecken fresser im Nildelta (Limnogeton fieberi Mayr) (Belostomatidae, Hemiptera). Z Tropenmed Parasitol 17: 155-165.

Voelker J 1968. Untersuchungen zur Ernahrung, Fortpfanzungsbiologie und Entwicklung von Limnogeton fieberi Mayr (Belostomatidae, Hemiptera) als bertrag zur Kenntnis von naturlichen Feinden tropischer SuBwasserschnecken. Entom Mitt Zool Mus Hamburg 3: $1-24$.

Wilken GB, Appleton CC 1991. Avoidance responses of some indigenous and exotic freshwater pulmonate snails to leech predation in South Africa. SAf J Zool 26: 6-10. 